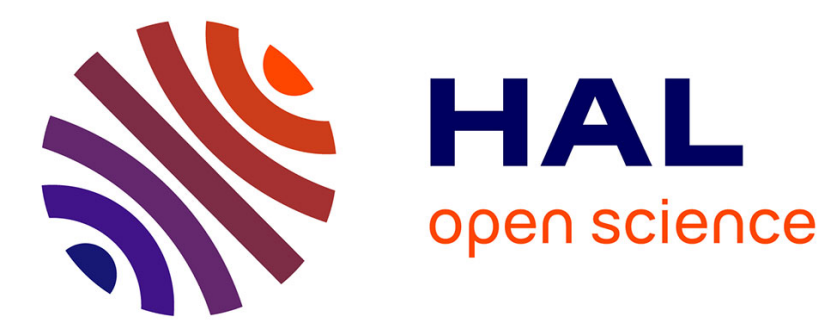

\title{
Trends in the ecological character of the world's wetlands
}

\author{
N. C Davidson, L. Dinesen, S. Fennessy, C. M. Finlayson, R. Mcinnes, P. \\ Grillas, A. Grobicki, R J Mcinnes B, D. A Stroud
}

\section{- To cite this version:}

N. C Davidson, L. Dinesen, S. Fennessy, C. M. Finlayson, R. Mcinnes, et al.. Trends in the ecological character of the world's wetlands. Marine and Freshwater Research, 2019, 71 (1), pp.127. 10.1071/MF18329 . hal-02505643

\section{HAL Id: hal-02505643 https://hal.science/hal-02505643}

Submitted on 16 Mar 2020

HAL is a multi-disciplinary open access archive for the deposit and dissemination of scientific research documents, whether they are published or not. The documents may come from teaching and research institutions in France or abroad, or from public or private research centers.
L'archive ouverte pluridisciplinaire HAL, est destinée au dépôt et à la diffusion de documents scientifiques de niveau recherche, publiés ou non, émanant des établissements d'enseignement et de recherche français ou étrangers, des laboratoires publics ou privés. 


\section{Trends in the ecological character of the world's wetlands}

N. C. Davidson A,Bj, L. Dinesen C, S. Fennessy D, C. M. Finlayson ${ }^{B, E}$, P. Grillas F, A. Grobicki ${ }^{\text {G, R. J. Mclnnes }}{ }^{\text {B,H }}$ and D. A. Stroud '

A Nick Davidson Environmental, Queens House, Ford Street, Wigmore, HR6 9UN, UK.

${ }^{B}$ Institute for Land, Water \& Society, Charles Sturt University, Elizabeth Mitchell Drive, PO Box 789, Albury, NSW 2640, Australia.

C Globe Institute, Center for Macroecology, Evolution and Climate, University of Copenhagen,

Universitetsparken 15, building 3, 3rd floor, DK-2100 Copenhagen, Denmark.

D Kenyon College, 106 College Park Drive, Gambier, OH 43022, USA.

EIHE Delft, Institute for Water Education, PO Box 3015, NL-2601 DA Delft, Netherlands

F La Tour du Valat - Research Institute for the Conservation of Mediterranean Wetlands, Le Sambuc, F-13200 Arles, France.

${ }^{G}$ Green Climate Fund, Songdo Business District, 175 Art Center-daero, Yeonsu-gu, Incheon 22004, South Korea.

${ }^{H}$ RM Wetlands \& Environment, 6 Ladman Villas, Littleworth, Oxfordshire, SN7 8EQ, UK.

I Joint Nature Conservation Committee, Monkstone House, City Road, Peterborough, PE1 1JY, UK.

J Corresponding author. Email: arenaria.interpres@gmail.com

How to cite: Davidson N. C., Dinesen L., Fennessy S., Finlayson C. M., Grillas P., Grobicki A., Mclnnes R. J., Stroud D. A. (2019) Trends in the ecological character of the world's wetlands. Marine and Freshwater Research 71, 127-138. https://doi.org/10.1071/MF18329

\section{Abstract.}

We assessed trends in the ecological character of wetlands generally and of Ramsar Sites reported in 2011, 2014 and 2017 by the Contracting Parties to the Ramsar Convention on Wetlands in their national reports. There was more widespread deterioration than improvement in the ecological character of wetlands generally, with deterioration increasingly more widespread between 2011 and 2017. The ecological-character trends in Ramsar Sites were significantly better than those of wetlands generally, but an increasingly more widespread deterioration of ecological character was reported between 2011 and 2017. Trends in the ecological character of wetlands generally, and of Ramsar Sites were worst in Africa and Latin America and the Caribbean, and recently also in Oceania, and better in North America and Europe. Deterioration in the ecological character of Ramsar Site was more widespread in countries with a large average area of their Ramsar Sites. This information on trends of wetland ecological character can contribute to assessing the achievement ofthe 2030 Sustainable Development Goal Target 6.6 and Aichi Biodiversity Target 5. Our analysis indicated that the 1971 aim of the Ramsar Convention to stem the degradation of wetlands has not yet been achieved.

Additional keywords: Ramsar Convention, Ramsar Sites, Sustainable Development Goals, wetland assessment

\section{Introduction}

In the 1960s, there was increasing recognition of a widespread and ongoing wetland conversion and degradation, which led to the signing by governments of the global 'Ramsar Convention on Wetlands' in 1971 (Ramsar Convention 1971; Carp 1972). The text of the Convention recognised the great value of wetlands to people 'the loss of which would be irreparable' and expressed the aim to 'stem the progressive encroachment on and loss of wetlands now and in the future' (Ramsar Convention 1971, p. 1), through the wise use of all wetlands, the designation and management of Wetlands of International Importance (Ramsar Sites) and international cooperation (Matthews 1993; de Klemm 1995; Ramsar Convention Secretariat 2011).

These views about the importance of wetlands to people have been amply reaffirmed subsequently, with wetlands now being recognised as delivering a wide range of ecosystem services (benefits to people) crucial for livelihoods and wellbeing (Finlayson et al. 2005; Ramsar Convention on Wetlands 2018) and of great monetary value, with wetlands delivering $43 \%$ of the monetary value delivered by all natural biomes, despite their forming less than $4 \%$ of the earth's surface (Davidson et al. 2019). The maintenance and sustainable management of wetlands is recognised as a critical issue for climate-change mitigation and adaptation (IPCC 2019). Many wetlands such as peatlands, mangroves, saltmarshes and seagrass beds can also play a vital role in mitigating climate change through their extensive CO2 sequestration and storage (Moomaw et al. 2018; Ripple et al. 2019). 
Although originally applying only to designated Ramsar Sites (Ramsar Convention 1971), the Convention recognised, in 2005, that the mechanism to achieve the wise use of all wetlands is the maintenance of their 'ecological character'. The ecological character of wetlands is defined by the Convention as follows: 'the combination of the ecosystem components, pro-cesses and benefits/services that characterise the wetland at a given point in time' (Ramsar Convention 2005, p. 5).

Over time, the Convention has established several different reporting mechanisms for ecological character and the change in the ecological character of Ramsar Sites and for all wetlands; however, Davidson et al. (2020) concluded that most of these mechanisms are being inadequately applied by Contracting Parties and are insufficient to provide global information on the ecological-character status and the change in the status of wetlands.

There is increasing evidence that the global area (i.e. quantity) of natural wetlands has been decreasing for centuries, and is continuing to decrease (Davidson 2014; Dixon et al. 2016; Darrah et al. 2019). However, there is much less readily available information on the quality, i.e. the state of the ecological character, and changes in that state, of the world's remaining wetlands. Yet, such knowledge of the state and trends of the ecological character of wetlands is crucial to better inform policy-makers to help guide adoption of future policy and prioritisation of implementation of the Ramsar Convention.

In the 2000s, recognising this considerable knowledge gap, the Ramsar Convention's Scientific \& Technical Review Panel (STRP) developed a question (Indicator question 1.1.4), which was included in the Ramsar triennial national reports to the 10th meeting of the Conference of the Contracting Parties (COP10), seeking the views of the Convention's Contracting Parties on trends in the ecological character of their wetlands. However, subsequent assessment of the national-report answers to this question identified ambiguities in both its wording and interpretation. Consequently, this question was revised and simplified for COP11 national reports (provided by Contracting Parties in 2011), and has been repeated verbatim in subsequent national reports, in 2014 to COP12 and 2017 to COP13.

This indicator question (1.1.3) concerns, at a national scale, the change in the ecological character of wetlands, and is as follows: 'has the condition of wetlands in your country, overall, and Ramsar Sites, changed since the last triennium', for (1) Ramsar Sites and (2) wetlands generally? Answer options are 'improved', 'no change' or 'deteriorated'. The same indicator question, for individual Ramsar Sites, was in an optional section of COP11 and COP12, but not COP13, national reports. The indicator question has an explanatory footnote that, for the purpose of reporting on this indicator, the word 'condition' means the 'ecological character' of wetlands, as defined by the Convention (see above).

This important Ramsar national report information has not previously been fully analysed. Here, we report on the trends of the ecological character of wetlands from national reports provided by Ramsar Contracting Parties to each triennial meeting of the COP for the three most recent reporting cycles, namely, COP11, COP12 and COP13. This is the only Ramsar

Convention reporting mechanism that is regularly applied by most Contracting Parties (Davidson et al. 2020). From this official Ramsar reporting mechanism, we assess whether, over the more than 45 years of the Ramsar Convention, the aim of the 1971 Convention to stem the deterioration of wetlands has been achieved. We also comment on how this indicator data can help inform progress towards the subsequently adopted 2020 Aichi targets for biodiversity and the 2030 United Nations Sustainable Development Goals (SDGs), as is recognised by the Global Wetland Outlook ofthe Ramsar Convention (Ramsar Convention on Wetlands 2018).

\section{Materials and methods}

We analysed the answers for the national-scale ecologicalcharacter change of wetlands generally and of Ramsar Sites provided by the Contracting Parties to the national report Indicator question 1.1.3 in their COP11 and COP12 national reports, the same indicator question (numbered 8.5) in COP13 national reports and the optional national report Section 4 answers for individual Ramsar Sites in COP11 and COP12 national reports. All national reports are available on the Ramsar website (http:// www.ramsar.org, accessed 4 November 2019). The numbers of reports for each trend in ecological character are provided in Table S1 (available as Supplementary material to this paper). 
These national-report answers reflect the perceptions of Ramsar's national administrative authorities (the institution in each country responsible for Convention implementation) and Ramsar Site managers. Although these are official reports from governments, the responses are not independently verifiable because the source information is not requested or referenced in their national reports.

We calculated an Ecological Character-Status Index (ECSI) to provide a single, comparable metric of ecologicalcharacter status, applying a method first used by Butchart et al. (2010) and Wetlands International (2010). The reported trend in ecological character is allocated a score of either +1 'improved', 0 'no change', or -1

'deteriorated'. The ECSI is calculated as:

$$
\left(n_{+1}-n_{-1}\right)-. n_{\text {total }}
$$

The index, thus, factors in the number of reports of 'no change'. The ECSI range is from +1 (all improved) to -1 (all deteriorated).

We report our results using the following two terms: 'trend in the ecological character' refers to trends reported in a single set of COP national reports (e.g. in COP11 or COP12 reports); and 'change in the trend in the ecological character' refers to comparisons of reported trends between different sets of national reports (e.g. comparison of trends reported between COP11 and COP12 national reports).

For national-level Contracting-Party reports of the trend in the ecological character of Ramsar Sites, we assessed whether this trend was related to the number, the total area and the average area of Ramsar Sites in each country. In these analyses, we have to make the assumption that the ecological-character trend of all Ramsar Sites in a country is the same. Although this is unlikely (except for countries with only one Ramsar Site), in the absence of better information on the trend of each individual Ramsar Site these are the best assessments currently achievable (see also Davidson et al. 2020).

\begin{tabular}{|c|c|c|c|c|c|c|}
\hline \multirow[b]{2}{*}{ Year of report and region } & \multicolumn{5}{|c|}{ Ecological-character trend (percentage of CPs reporting) } & \multirow[b]{2}{*}{$P$} \\
\hline & $\begin{array}{l}\text { Number of national- } \\
\text { report responses }\end{array}$ & Deterioration & No change & Improvement & $\begin{array}{l}\text { Ecological Character- } \\
\text { Status Index (ECSI) }\end{array}$ & \\
\hline \multicolumn{7}{|l|}{2011 (COP1 1 national reports) } \\
\hline Africa & 36 & 33.33 & 33.33 & 33.33 & 0 & $\mathrm{n} . \mathrm{s}$. \\
\hline Asia & 20 & 55.00 & 25.00 & 20.00 & -0.350 & $\mathrm{n} . \mathrm{s}$. \\
\hline Europe & 38 & 15.79 & 73.68 & 10.53 & -0.053 & ns. \\
\hline Latin America and Caribbean & 18 & 38.89 & 27.78 & 33.33 & -0.056 & $\mathrm{n} s$. \\
\hline North America & 3 & 33.33 & 33.33 & 33.33 & 0 & - \\
\hline Oceania & 7 & 28.57 & 42.86 & 28.57 & 0 & - \\
\hline Global (all regions) & 122 & 31.97 & 44.26 & 23.77 & -0.082 & $\mathrm{n} . \mathrm{s}$. \\
\hline \multicolumn{7}{|l|}{2014 (COP12 national reports) } \\
\hline Africa & 45 & 57.78 & 28.89 & 13.33 & -0.444 & $<0.001$ \\
\hline Asia & 26 & 42.31 & 38.46 & 19.23 & -0.231 & n.s. \\
\hline Europe & 39 & 30.77 & 61.54 & 7.69 & -0.205 & 0.039 \\
\hline Latin America and Caribbean & 19 & 42.11 & 42.11 & 15.79 & -0.263 & $\mathrm{n} . \mathrm{s}$. \\
\hline North Amcrica & 3 & 66.67 & 33.33 & 0.00 & -0.667 & - \\
\hline Oceania & 7 & 28.57 & 57.14 & 14.29 & -0.143 & - \\
\hline Global (all regions) & 139 & 43.88 & 43.17 & 12.95 & -0.309 & $<0.0001$ \\
\hline \multicolumn{7}{|l|}{2017 (COP13 national reports) } \\
\hline Africa & 44 & 54.55 & 38.64 & 6.82 & -0.477 & 0.0001 \\
\hline Asia & 27 & 51.85 & 37.04 & 11.11 & -0.407 & 0.0153 \\
\hline Europe & 38 & 18.42 & 76.32 & 5.26 & -0.132 & $\mathrm{n} s$. \\
\hline Latin America and Caribbean & 23 & 34.78 & 52.17 & 13.04 & -0.217 & $\mathrm{n} s$. \\
\hline North America & 3 & 33.33 & 33.33 & 33.33 & 0 & - \\
\hline Oceania & 6 & 66.67 & 33.33 & 0 & -0.667 & - \\
\hline Global (all regions) & 141 & 41.13 & 50.35 & 8.51 & -0.326 & $<0.0001$ \\
\hline
\end{tabular}

Table 1. National-scale ecological-character status of wetlands generally, as reported by Contracting Parties (CPs) in 2011 (the 11th meeting of the Conference of the Contracting Parties (COP11) national reports), 2014 (COP12 national reports) and 2017 (COP13 national reports). $P$ is the probability of the numbers of reports of deterioration and of improvement being significantly different (X2 goodness-of-fit tests). Numbers of reports from North America and Oceania were too small to test for significance. n.s., not significant

For wetlands generally, it was not possible to make a similar assessment of the trend in the ecological character in 
relation to the national wetland area, because there is no comprehensive national wetland-inventory information available for many countries (Finlayson et al. 1999; Davidson et al. 2018).

Differences between the numbers of reports of an improved and those of reports of a deteriorated ecological character were tested with Chi-Square 'goodness-of-fit' tests, with the null hypothesis of equal numbers of the two trends; differences among the numbers of 'increased', 'no change' and 'deteriorated' reports were tested with ChiSquare tests; correlations between the Ramsar Site status and Ramsar Site numbers, and the total national area and average national area were tested using Spearman rank correlations ( $r s)$. Statistical analyses were conducted using VassarStats (http://vassarstats.net/index.html, accessed 5 November 2019).

\section{Results}

\section{Trends in the ecological character of wetlands generally}

Of the 145 COP11 national reports submitted, 122 parties reported on the trend in the ecological character of wetlands generally. A similar level of reporting was made by parties in their COP12 reports, namely, of 150 national reports submitted, 139 reported on wetlands generally; and in their COP13 reports, where, of 150 national reports submitted, 141 reported on wetlands generally. A total of 111 parties reported to both COP11 and COP12 on wetlands generally.

In 2011 (national reports to COP11), 122 Contracting Parties (CPs) reported a slightly, but not significantly, more widespread national-scale deterioration than improvement in the ecological character of their wetlands generally, with a global ECSI of -0.082 (Table 1, Fig. 1).

The pattern of trends differed significantly among regions $(X 2, P=0.0034)$. Regionally (Table 1 , Fig. 1$)$, the most widespread national deterioration of the ecological character of wetlands generally, in 2011, was reported from Asia and Latin America and the Caribbean, and the least widespread deterioration was reported from Europe and Oceania. Conversely, the least widespread improvement was reported from Europe and Asia. Almost three-quarters of European countries and more than $40 \%$ of Oceania countries reported no change in the ecological character of their wetlands generally. Overall, the ecological character trends (ECSI) were worst in Asia, and none of the regions reported more widespread improvement than deterioration (Table 1, Fig. 1).

The 139 CPs reporting in 2014 (national reports to COP12) reported a significantly more widespread national-scale deterioration than improvement in the ecological character of their wetlands generally, with a global ECSI of -0.309 (Table 1, Fig. 1).

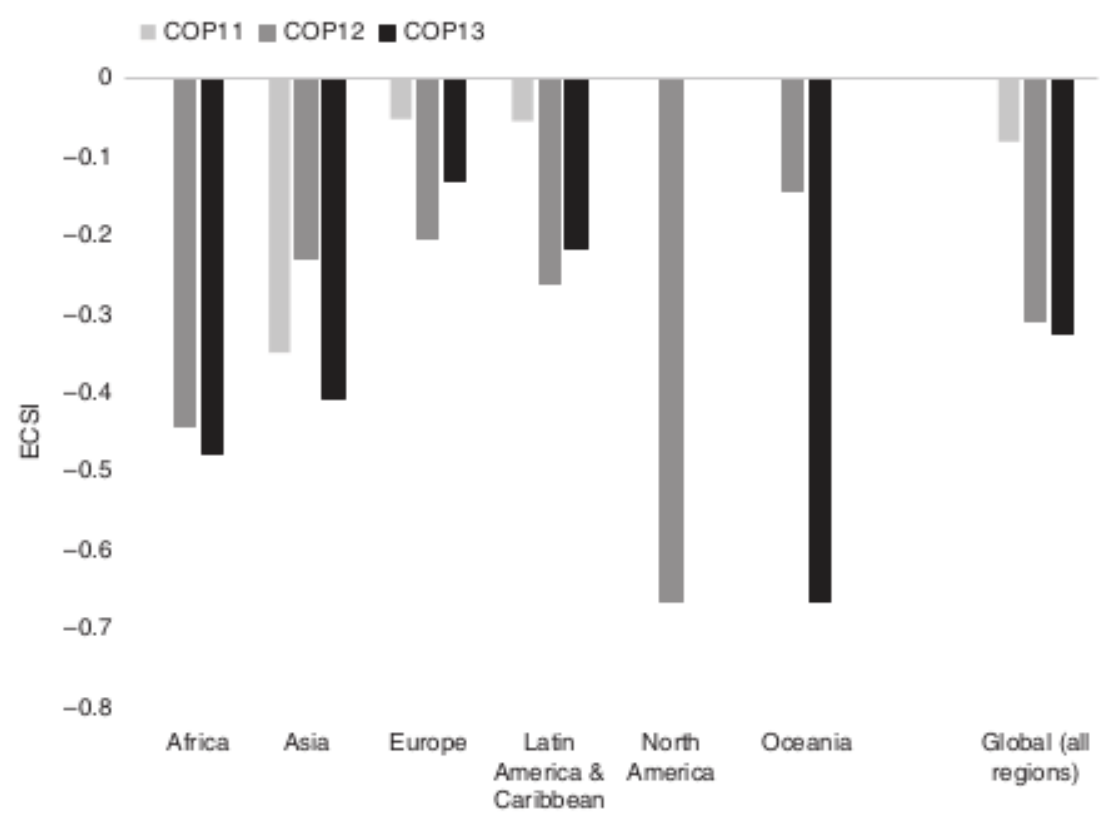


In 2014, there was a more widespread deterioration than improvement of wetlands generally (negative ECSIs) in all six regions, significantly so for Africa and Europe (Table 1, Fig. 1). The most widespread national-scale deterioration of wetlands generally was reported from North America, Africa, Asia and Latin America and the Caribbean, with the least widespread deterioration being reported from Europe and Oceania. Conversely, the most widespread improvement in the ecological character was reported from Asia, Latin America and the Caribbean and Oceania and the least widespread improvement from North America and Europe. A high proportion of European and Oceanian countries reported no change in the ecological character of their wetlands generally.

In 2017, COP13 reports indicated a continuing more widespread deterioration than improvement in the ecological character of wetlands generally, globally and for five of the six regions (the exception being for the three countries of North America), with this trend being significant globally and for Africa and Asia (Table 1, Fig. 1).

Globally, the change in the trend of the ecological character of wetlands generally was a significant deterioration between 2011 and 2014 (Table 2, Fig. 2). This more widespread deterioration in 2014 than 2011 was reported from five of the six regions, with the greatest, and significant, deterioration being in Africa. The exception was Asia with a small, but not significant, improvement. Between 2014 and 2017, globally, there was a small, but not significant, further deterioration, with further deterioration being reported for Africa, Asia and Oceania, but improvement in Europe, Latin America and the Caribbean and North America (Table 2, Fig. 2). Across the full 2011-2017 reporting period, there was a significant global increase in the extent of ecological-character deterioration, with deterioration being reported in five of the six regions (significantly so for Africa; Table 2, Fig. 2). The greatest long-term deterioration was reported in Africa (ECSI -0.477) and the small number of countries in Oceania (ECSI -0.667).

Considering only the 111 CPs who reported to both COP11 and COP12 on the ecological character of their wetlands generally, the results are closely similar to those for all parties reporting to each COP. Globally, the COP11 ECSI was -0.082 (compared with -0.063 for all parties reporting) and the COP12 ECSI was -0.306 (compared with -0.309 for all parties reporting). As for all parties reporting, there was a significantly more widespread deterioration in the ecological character of all wetlands generally in 2014 than in $2011(X 2, P=0.044)$.

\section{Trends in the ecological character of Ramsar Sites: national scale reports}

Of the 145 COP11 national reports submitted, 137 parties reported on the trend in the ecological character of Ramsar Sites at the national level. There was a similar level of reporting by parties in COP12 reports, where, of the 150 national reports submitted, 147 reported on Ramsar Sites; and in COP13 reports, where, of the 150 national reports submitted, 144 reported on Ramsar Sites. In total, 128 parties reported to both COP11 and COP12 on Ramsar Sites.

In 2011, in their national reports to COP11, CPs reported that globally there was a significantly more widespread nationalscale improvement than deterioration of the ecological character of designated Ramsar Sites, with a global ECSI of +0.153 (Table 3, Fig. 3). The patterns oftrend did not differ significantly among regions $(X 2, P=0.1283$ ) and, although a more widespread improvement than deterioration (positive ECSIs) was reported for Ramsar Sites in all regions, none was significant (Table 3, Fig. 3). The most widespread improvement in the status of Ramsar Sites was reported from Asia and Oceania, with the least widespread improvement being reported from Europe and Latin America and the Caribbean. Conversely, the most widespread deterioration in Ramsar-Site status was reported from Africa and Latin America and the Caribbean (Table 3). More than half (54\%) of countries globally reported no change in the ecological-character status of all their Ramsar Sites, with over $70 \%$ of European countries reporting no change (Table 3). The reported ecological-character status (ECSI) of Ramsar Sites was best in Oceania and Asia and worst in Africa and Latin America and the Caribbean (Table 3, Fig. 3). 


\begin{tabular}{|c|c|c|c|}
\hline Comparison and region & $\begin{array}{l}\text { Number of national-report } \\
\text { responses }\end{array}$ & $\begin{array}{l}\text { ECSI } \\
\text { change }\end{array}$ & $P$ \\
\hline \multicolumn{4}{|c|}{ (1) COP1 $1 v$. COP12 reports } \\
\hline Africa & $36 ; 45$ & -0.444 & 0.043 \\
\hline Asia & $20 ; 26$ & 0.119 & n.s. \\
\hline Europe & $38 ; 39$ & -0.178 & n.s. \\
\hline $\begin{array}{l}\text { Latin America and } \\
\text { Caribbean }\end{array}$ & $18 ; 19$ & -0.207 & n.s. \\
\hline North America & $3 ; 3$ & -0.667 & - \\
\hline Oceania & $7 ; 7$ & -0.143 & - \\
\hline Global (all regions) & $122 ; 139$ & -0.227 & 0.036 \\
\hline \multicolumn{4}{|c|}{ (2) COP12v. COP13 reports } \\
\hline Africa & $45 ; 44$ & -0.033 & n.s. \\
\hline Asia & $26 ; 27$ & -0.176 & n.s. \\
\hline Europe & $39 ; 38$ & 0.073 & n.s. \\
\hline $\begin{array}{l}\text { Latin America and } \\
\text { Caribbean }\end{array}$ & $19 ; 23$ & 0.046 & n.s. \\
\hline North America & $3 ; 3$ & 0.667 & - \\
\hline Oceania & $7 ; 6$ & -0.524 & - \\
\hline Global (all regions) & $139 ; 141$ & -0.017 & n.s. \\
\hline \multicolumn{4}{|c|}{ (3) COP11 v. COP13 reports } \\
\hline Africa & $36 ; 44$ & -0.477 & 0.008 \\
\hline Asia & $20 ; 27$ & -0.057 & n.s. \\
\hline Europe & $38 ; 38$ & -0.079 & n.s. \\
\hline $\begin{array}{l}\text { Latin America and } \\
\text { Caribbean }\end{array}$ & $18 ; 23$ & -0.161 & n.s. \\
\hline North America & $3 ; 3$ & 0 & - \\
\hline Oceania & $7 ; 6$ & -0.667 & - \\
\hline Global (all regions) & $122 ; 141$ & -0.244 & 0.003 \\
\hline
\end{tabular}

Table 2. Change in the national-scale trends of ecological character (as indicated by Ecological Character-Status Index, ECSI) of wetlands generally among the reports from the 11th, 12th and 13th meetings of the Conference of the Contracting Parties (COP11, COP12 and COP13) P is the probability of the numbers of reports of deterioration, no change and improvement being significantly different between COP reports (chi-square tests). Numbers of reports from North America and Oceania were too small

to test for significance. n.s., not significant

As in 2011, in 2014 (national reports to COP12), globally, the 147 CPs reporting on the status of their Ramsar Sites reported a more widespread improvement than deterioration, with a global ECSI of +0.061 , but, unlike in 2011, the difference was not significant (Table 3, Fig. 3). However, the patterns of trend differed significantly among regions $(\mathrm{X} 2, \mathrm{P}=0.0044)$. Four regions reported a slightly more widespread improvement than deterioration and two regions (Africa and Latin America and the Caribbean) reported a slightly more widespread deterioration than improvement, but none of these was significant (Table 3, Fig. 3). As for 2011 reports, more than half (57\%) of countries globally reported no change in the ecological-character status of all their Ramsar Sites, with particularly high percentages reporting no change in Asia (74\%), Europe (72\%) and North America (67\%; Table 3).

In 2017 (national reports to COP13), globally, equal numbers of the 144 CPs reported improvement and deterioration $(E C S I=0)$, and, again, a high proportion (64\%) reported no change in the ecological character of their Ramsar Sites (Table 3). 


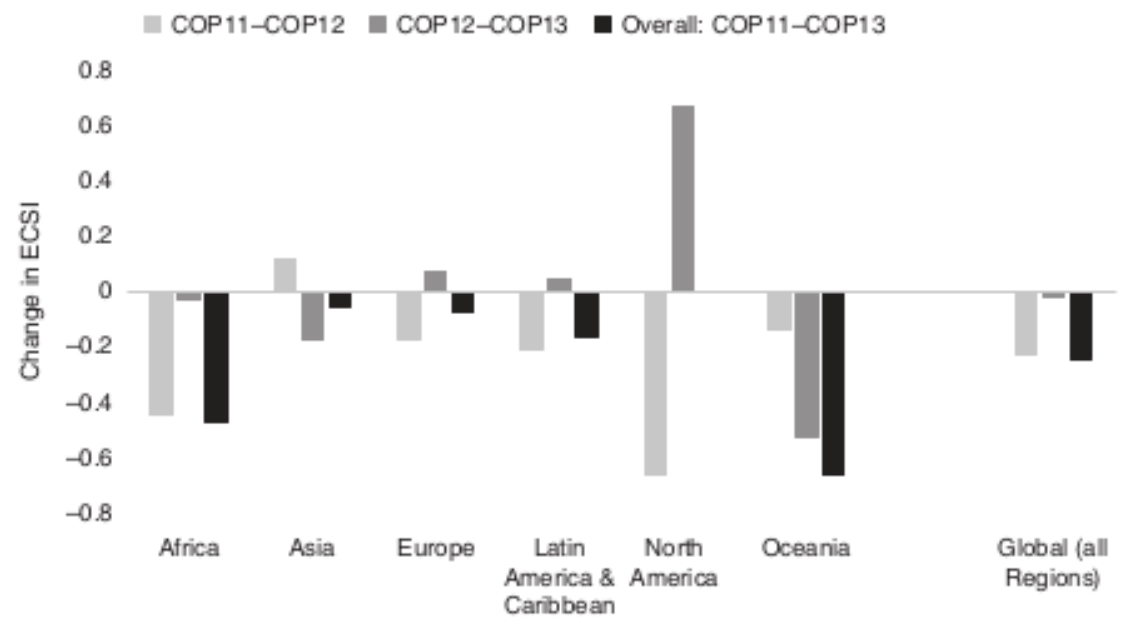

Fig. 2. Changes in the trends in the ecological character (as indicated by Ecological Character-Status Index, ECSI) of wetlands generally reported by Contracting Parties between 2011 (COP11 national reports), 2014 (COP12 national reports) and 2017 (COP13 national reports), and overall between 2011 and 2017. There was no change in the ECSI (ECSI change = 0) for North America between 2011 and 2017.

\begin{tabular}{|c|c|c|c|c|c|c|}
\hline \multirow[b]{2}{*}{ Year of report and region } & \multicolumn{6}{|c|}{ Ecological-character trend (percentage of CPs reporting) } \\
\hline & $\begin{array}{l}\text { Number of national- } \\
\text { report responses }\end{array}$ & Deterioration & No change & Improvement & ECSI & $P$ \\
\hline \multicolumn{7}{|l|}{2011 (COP11 national reports) } \\
\hline Africa & 43 & 25.58 & 41.86 & 32.56 & +0.070 & n.s. \\
\hline Asia & 23 & 13.04 & 43.48 & 43.48 & +0.304 & n.s. \\
\hline Europe & 39 & 7.69 & 71.79 & 20.51 & +0.128 & n.s. \\
\hline Latin America and Caribbean & 22 & 18.18 & 54.55 & 27.27 & +0.091 & n.s. \\
\hline North America & 3 & 0.00 & 66.67 & 33.33 & +0.333 & - \\
\hline Oceania & 7 & 0.00 & 57.14 & 42.86 & +0.429 & - \\
\hline Global (all regions) & 137 & 15.33 & 54.01 & 30.66 & +0.153 & 0.012 \\
\hline \multicolumn{7}{|l|}{2014 (COP12 national reports) } \\
\hline Africa & 45 & 33.33 & 37.78 & 28.89 & -0.044 & n.s. \\
\hline Asia & 27 & 3.70 & 74.07 & 22.22 & +0.185 & n.s. \\
\hline Europe & 43 & 9.30 & 72.09 & 18.60 & +0.093 & n.s. \\
\hline Latin America and Caribbean & 22 & 31.82 & 45.45 & 22.73 & -0.091 & n.s. \\
\hline North America & 3 & 0.00 & 66.67 & 33.33 & +0.333 & - \\
\hline Oceania & 7 & 0.00 & 57.14 & 42.86 & +0.429 & - \\
\hline Global (all regions) & 147 & 18.37 & 57.14 & 24.49 & +0.061 & n.s. \\
\hline \multicolumn{7}{|l|}{2017 (COP13 national reports) } \\
\hline Africa & 44 & 25.00 & 56.86 & 18.18 & -0.068 & n.s. \\
\hline Asia & 28 & 14.29 & 60.71 & 25.00 & +0.107 & n.s. \\
\hline Europe & 40 & 7.50 & 75.00 & 17.50 & +0.100 & n.s. \\
\hline Latin America and Caribbean & 23 & 26.09 & 56.52 & 17.39 & -0.087 & n.s. \\
\hline North America & 3 & 0 & 100 & 0 & 0 & - \\
\hline Oceania & 6 & 33.33 & 66.67 & 0 & -0.333 & - \\
\hline Global (all regions) & 144 & 18.06 & 63.89 & 18.06 & 0 & n.s. \\
\hline
\end{tabular}

Table 3. National-scale ecological-character status of Ramsar Sites, as reported by Contracting Parties (CPs) in 2011 (the 11th meeting of the Conference of the Contracting Parties (COP11) national reports), 2014 (COP12 national reports) and 2017 (COP13 national reports). $P$ is the probability of the numbers of reports of deterioration and of improvement being significantly different (X2 goodness-of-fit tests); n.s., not significant.

Numbers of reports from North America and Oceania were too small to test for significance. ECSI, Ecological Character-Status Index 


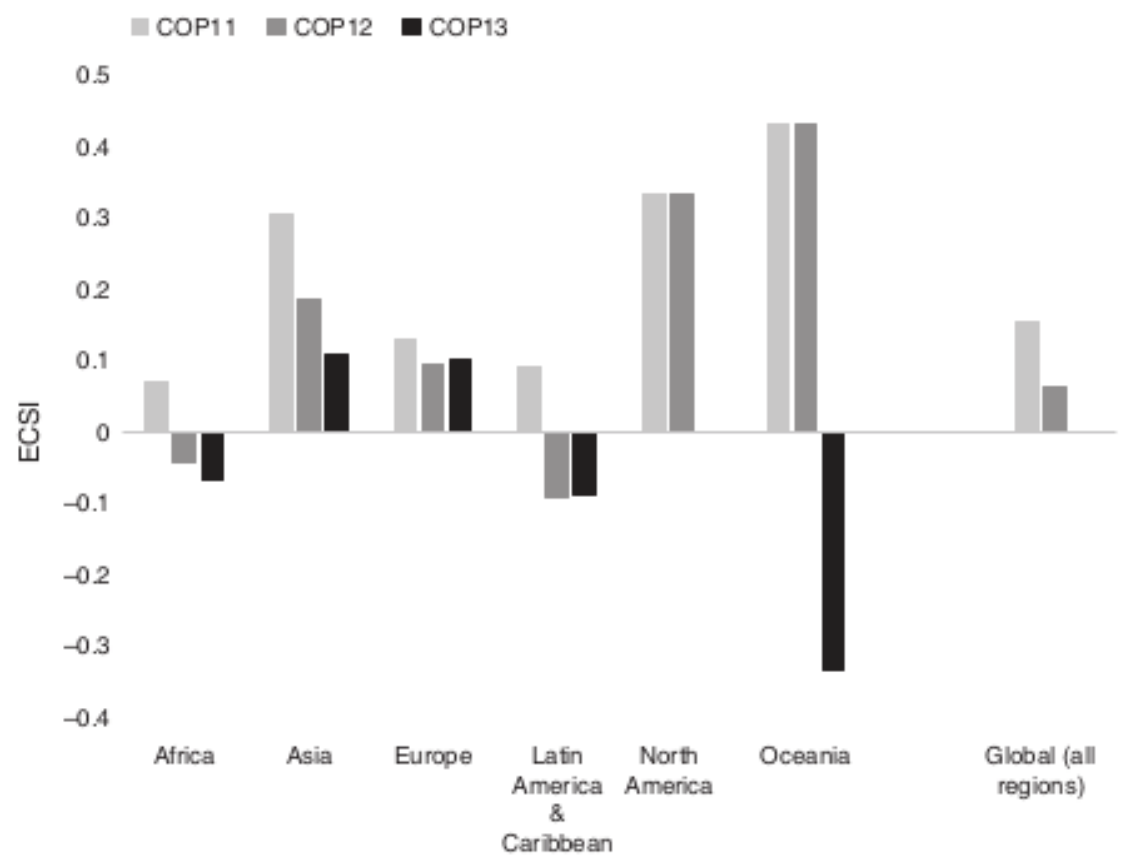

Fig. 3. Regional and global Ecological Character-Status Indices (ECSIs) for Ramsar Sites reported at a national-scale by Contracting Parties in 2011 (COP11 national reports), 2014 (COP12 national reports) and 2017 (COP13 national reports). ECSIs for North America and global for COP13 were 0 (i.e. an equal number of reports of deterioration and improvement).

\begin{tabular}{|c|c|c|c|}
\hline $\begin{array}{l}\text { Comparison and } \\
\text { region }\end{array}$ & $\begin{array}{l}\text { Number of national- } \\
\text { report responses }\end{array}$ & ECSI change & $P$ \\
\hline \multicolumn{4}{|c|}{ (1) COP11 v. COP12 reports } \\
\hline Africa & $43 ; 45$ & -0.114 & n.s. \\
\hline Asia & $23 ; 27$ & -0.119 & n.s. \\
\hline Europe & $39 ; 43$ & -0.035 & n.s. \\
\hline $\begin{array}{l}\text { Latin America and } \\
\text { Caribbean }\end{array}$ & $22 ; 22$ & -0.182 & n.s. \\
\hline North America & $3 ; 3$ & 0 & - \\
\hline Oceania & $7 ; 7$ & 0 & - \\
\hline Global (all regions) & $137 ; 147$ & -0.092 & n.s. \\
\hline \multicolumn{4}{|c|}{ (2) COP12v. COP13 reports } \\
\hline Africa & $45 ; 44$ & -0.024 & n.s. \\
\hline Asia & $27 ; 28$ & -0.078 & n.s. \\
\hline Europe & $43 ; 40$ & 0.007 & n.s. \\
\hline $\begin{array}{l}\text { Latin America and } \\
\text { Caribbean }\end{array}$ & $22 ; 23$ & 0.004 & n.s. \\
\hline North America & $3 ; 3$ & -0.333 & - \\
\hline Oceania & $7 ; 6$ & -0.762 & - \\
\hline Global (all regions) & $147 ; 144$ & -0.061 & n.s. \\
\hline \multicolumn{4}{|c|}{ (3) COP1 $1 v$. COP13 reports } \\
\hline Africa & $43 ; 44$ & -0.138 & n.s. \\
\hline Asia & $23 ; 28$ & -0.197 & 0.026 \\
\hline Europe & $39 ; 40$ & -0.028 & n.s. \\
\hline $\begin{array}{l}\text { Latin America and } \\
\text { Caribbean }\end{array}$ & $22 ; 23$ & -0.178 & n.s. \\
\hline North America & $3 ; 3$ & -0.333 & - \\
\hline Oceania & $7 ; 6$ & -0.762 & - \\
\hline Global (all regions) & $137 ; 144$ & -0.153 & 0.045 \\
\hline
\end{tabular}

Table 4. Change in the national-scale trends of the ecological character (ECSI) of Ramsar Sites among the reports from the 11th, 12th and 13th meetings of the Conference of the Contracting Parties (COP11, COP12 and COP13) $P$ is the probability of the numbers of reports of deterioration, no change and improvement being significantly different among the COP reports (X2 tests). Numbers ofreports fromNorth America and Oceania were too small to test for significance. ECSI, Ecological Character-Status Index; n.s., not significant 
Two regions (Asia and Europe) reported a more widespread improvement than deterioration, but three regions (Africa, Latin America and the Caribbean and Oceania) reported the converse, although none of these differences within regions was significant (Table 3). Overall, in 2017, the ecological character of Ramsar Sites in over $80 \%$ of countries was reported as not changing or improving.

The global ecological character of Ramsar Sites deteriorated slightly, but not significantly, between 2011 and 2014, with an ECSI change of -0.092 (Table 4, Fig. 4). A more widespread, but not significant, deterioration in 2014 was reported from four regions (Africa, Asia, Europe and Latin America and the Caribbean), with most deterioration in Latin America and the Caribbean (Table 4). No change between 2011 and 2014 was reported from North America and Oceania (Table 4, Fig. 4). There was a further slight deterioration in the ecological character of Ramsar Sites between 2014 and 2017 (ECSI change -0.061), but no regional or global changes were significant (Table 4, Fig. 4). However, across the full 2011-2017 reporting period assessed, the global deterioration in the ecological character of Ramsar Sites (ECSI change - 0.153) was significant. This deterioration occurred across all six regions, but was significant only for Asia (Table 4).

Results from the 128 CPs who reported to both COP11 and COP12 on the trend in the Ramsar-Site ecological character were very similar to those for all parties reporting to each COP (see above). Globally, the COP11 ECSI was +0.180 (compared with +0.153 for all parties reporting), with a significantly more widespread national-scale improvement than deterioration occurring $(X 2, P=0.004)$. The COP12 ECSI was +0.063 (compared with +0.061 for all parties reporting), and, as for all parties reporting, the ECSI change (of -0.117) from 2011 to 2014 was not significant.

\section{Trends in the ecological character of individual RamsarSites}

For Section 4 in the national reports in 2011, only eight CPs (6\% of the 144 parties reporting to COP11) reported on 152 indi-vidual Ramsar Sites. Such reports were submitted only by a few European (4), African (2) and Latin America and the Caribbean (2) parties; no parties from Asia, North America or Oceania reported on their individual Ramsar Sites. We considered that this small number of reports and their limited geographical spread was insufficient for inclusion in the present analysis.

In 2014, 18 of the 148 CPs reporting to COP12 reported trends in the ecological-character status individually for each of their Ramsar Sites. In addition, a further 16 CPs, each with only a single Ramsar Site, answered the national-scale indicator question for Ramsar-Site trend. Combining these sources, we analysed the trend of 324 individual Ramsar Sites ( $14 \%$ of all Ramsar Sites) in 34 CPs ( $20 \%$ of the CPs). The national report format for COP13 did not include this option of reporting on the trend in the ecological character of individual Ramsar Sites.

From the sample of 324 Ramsar Sites the ecologicalcharacter trend of which was reported on individually to COP12 in 2014 (Table 5), 84\% of the sites had no change in their ecological character, which was a higher percentage than the $57 \%$ of parties reporting no change at the national scale (Table 3), with only $9 \%$ improving and $7 \%$ deteriorating. The global ECSI for individual Ramsar Sites was -0.019 , indicating a slightly, but not significantly, more widespread deterioration than improvement (Table 5). This compares with the slightly more widespread improvement in Ramsar-Site status (ECSI +0.061) from national-scale reporting in 2014 by all parties (Table 3 ). The overall difference between the reported nationalscale status and individual Ramsar-Site status was significant $(X 2, P<0.0001)$. Regionally (Table 5), two regions (Africa and Asia) reported a slightly more widespread deterioration than improvement of their individual Ramsar Sites, and two others (Europe and Oceania) reported a slightly more widespread improvement than deterioration, with Latin America and the Caribbean parties reporting a balance of improvement and deterioration $(\mathrm{ECSI}=0)$.

The trend in the Ramsar Site-status ECSIs for the only 17 CPs that provided reports in 2014, both at the national scale and for individual Ramsar Sites, was similar, namely, a slight deterioration in the Ramsar-Site status at the national scale (ECSI-0.023) and of individual Ramsar Sites (ECSI -0.022). However, within this overall picture, there was considerable variation in the comparative trend reported by these parties; eight parties reported the same trend in both categories, four reported a worse trend for individual Ramsar Sites than the national scale, and, conversely, five reported a better trend for individual Ramsar Sites than for their Ramsar Sites at the national scale.

Ramsar-Site characteristics affecting their trend in ecological character 


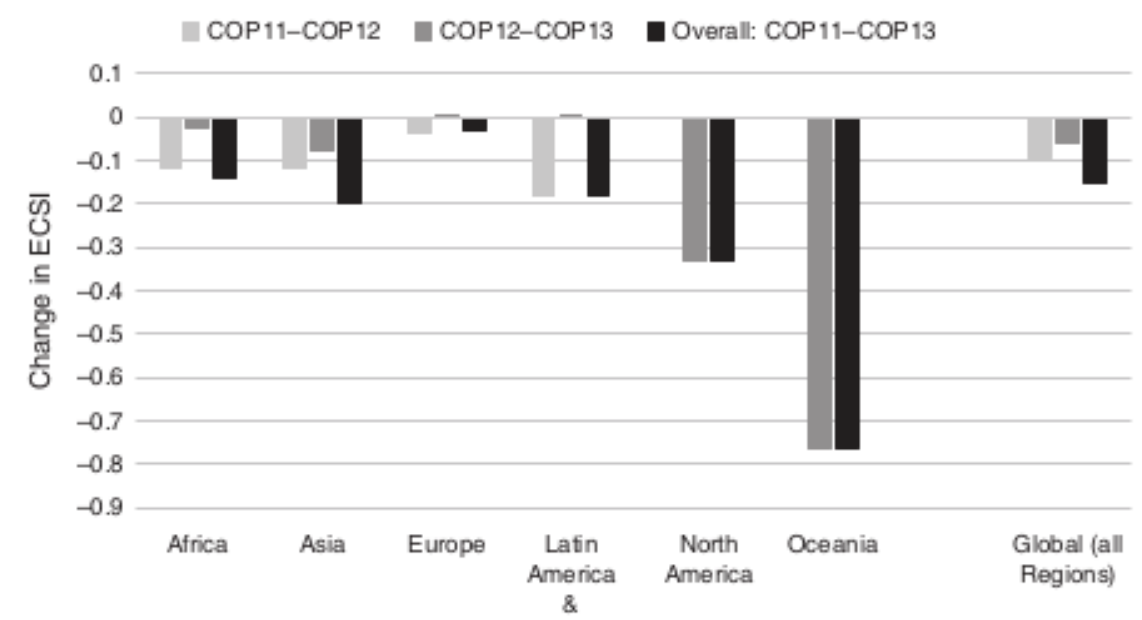

Fig. 4. Changes in the trends of the Ecological Character-Status Indices (ECSIs) of Ramsar Sites reportedby Contracting Parties among 2011 (COP11 national reports), 2014 (COP12 national reports) and 2017 (COP13 national reports), and overall between 2011 and 2017. There was no change in the ECSIs for Ramsar sites in North America and Oceania between COP11 and COP12 reporting (ECSI change $=0)$.

\begin{tabular}{lccc}
\hline Region & $\begin{array}{c}\text { Number of CPs } \\
\text { reporting }\end{array}$ & $\begin{array}{c}\text { Number of Ramsar } \\
\text { Sites reported }\end{array}$ & ECSI \\
\hline Africa & 11 & 78 & -0.090 \\
Asia & 5 & 26 & -0.192 \\
Europe & 9 & 145 & +0.024 \\
Latin America and & 5 & 15 & 0 \\
$\quad$ Caribbean & 4 & 68 & +0.044 \\
Oceania & 34 & 324 & -0.019 \\
Global (All regions) & & & \\
\hline
\end{tabular}

Table 5. Ecological Character-Status Indices (ECSIs) for the trend in the ecological character of individual Ramsar sites reported in 2014 by Contracting Parties (CPs) in their 12th meeting of the Conference of the Contracting Parties (COP12) national reports

The national-report answers provide a single trend in the ecological-character score from each CP. So, for Ramsar Sites, these scores are equally weighted regardless of the number of Ramsar Sites designated by each party. However, the number of designated Ramsar Sites varies greatly among the CPs, from some having only one site (designated at the time of accession to the Convention) to others with many sites, with the greatest number of sites being in the United Kingdom (175) and Mexico (142). Similarly, the area of individual Ramsar Sites varies greatly (from $<1$ ha to $>6.5$ million hectares) as does the national total area of Ramsar Sites (national numbers, areas and average areas of Ramsar Sites are provided in Table S2 (available as Supplementary material).

The national-scale ecological-character status of Ramsar Sites reported by CPs in 2014 was not related to the total number of their Ramsar Sites (Spearman rank correlation: $N=147, r s=0.090, P(2$-tailed) $=0.278)$. National-scale Ramsar-Site status was slightly, but not quite significantly, negatively correlated with the total national area of Ramsar Sites (Spearman rank correlation: $\mathrm{N}=147, \mathrm{rs}=-0.152, \mathrm{P}(2$-tailed) $=0.068)$.

However, the national-scale ecological-character status of Ramsar Sites reported in 2014 was significantly negatively correlated with the average area of the Ramsar Sites of the CP (Spearman rank correlation: $\mathrm{N}=147, \mathrm{rs}=-0.194, \mathrm{P}$ (2-tailed) = 0.019); i.e. the larger the average area of Ramsar Sites in the country, the more likely it is that their ecological character was reported as deteriorating. 
Regions with a large average national Ramsar-Site area (Africa 515712 ha; Latin America and the Caribbean 154416 ha) are those that have also reported the poorest Ramsar-Site ecological character (Table 3, Fig. 3). Conversely, regions reporting a better Ramsar-Site status have mostly a smaller average national area of Ramsar Sites (Asia 82 578 ha; Europe 26650 ha; Oceania 24989 ha). The exception is the three countries of North America that reported improvement, but also have a relatively large average area of Ramsar Sites (154511 ha).

Only $18 \%$ of parties reported national-scale deterioration of the status of their Ramsar Sites in 2014 (Table 3); however, if the total area of Ramsar Sites in these countries is taken into account, it suggests that more than onequarter (28\%) of the global area of Ramsar Sites is deteriorating. It also suggests a more widespread deterioration than improvement of the Ramsar-Site area (ECSI -0.164).

\begin{tabular}{|c|c|c|c|}
\hline Region & $\begin{array}{l}\text { Number of national-report responses } \\
\text { (Ramsar sites; wetlands generally) }\end{array}$ & $\begin{array}{l}\text { ECSI difference between Ramsar } \\
\text { Sites and wetlands generally }\end{array}$ & $P$ \\
\hline \multicolumn{4}{|l|}{2011 (COP11 national reports) } \\
\hline Africa & $43 ; 36$ & +0.070 & n.s. \\
\hline Asia & $23 ; 20$ & +0.654 & n.s. \\
\hline Europe & $39 ; 38$ & +0.181 & n.s. \\
\hline Latin America and the Caribbean & $22 ; 18$ & +0.147 & n.s. \\
\hline North America & $3 ; 3$ & +0.333 & - \\
\hline Oceania & $7 ; 7$ & +0.429 & - \\
\hline Global (all regions) & $137 ; 122$ & +0.232 & 0.021 \\
\hline \multicolumn{4}{|l|}{2014 (COP12 national reports) } \\
\hline Africa & $45 ; 45$ & +0.400 & 0.048 \\
\hline Asia & $27 ; 26$ & +0.416 & 0.008 \\
\hline Europe & $43 ; 39$ & +0.324 & n.s. \\
\hline Latin America and the Caribbean & $22 ; 19$ & +0.172 & n.s. \\
\hline North America & $3 ; 3$ & +1.000 & - \\
\hline Oceania & $7 ; 7$ & +0.572 & - \\
\hline Global (all regions) & $147 ; 139$ & +0.370 & 0.0004 \\
\hline \multicolumn{4}{|l|}{2017 (COP13 national reports) } \\
\hline Africa & $44 ; 44$ & +0.409 & 0.016 \\
\hline Asia & $28 ; 27$ & +0.300 & 0.011 \\
\hline Europe & $40 ; 38$ & +0.232 & n.s. \\
\hline Latin America and the Caribbean & $23 ; 23$ & +0.130 & n.s. \\
\hline North America & $3 ; 3$ & 0 & - \\
\hline Oceania & $6 ; 6$ & +0.333 & - \\
\hline Global (all regions) & $144 ; 141$ & +0.326 & $<0.0001$ \\
\hline
\end{tabular}

Table 6. Differences in national-scale Ecological Character-Status Indices (ECSIs) between Ramsar sites and wetlands generally. $P$ is the probability of the numbers of reports of deterioration, no change and improvement being significantly different between Ramsar Sites and wetlands generally (X2 tests). Numbers of reports from North America and Oceania were too small to test for significance. n.s., not significant

Differences in ecological-character trends between Ramsar Sites and wetlands generally In their national-scale reports, CPs consistently reported across all regions and globally in 2011, 2014 and 2017 that their Ramsar Sites had a better ecological-character trend than did their wetlands generally (Table 6, Fig. 5). This difference was significant globally in all three reporting periods, and for Africa and Asia in both 2014 and 2017 (Table $6)$.

Reports from only those parties that reported on both Ramsar Sites and wetlands generally (COP11, 119 CPs; COP12, $139 \mathrm{CPs}$ ) gave the same results as did those from all parties that reported, showing significantly better Ramsar-Site ecological-character trends than were the trends of wetlands generally $(X 2$ : COP11, $P=0.002 ; C O P 12, P<0.0001)$. In summary, the overall pattern of trends in wetland ecological character (Fig. 5) shows that, although Ramsar Sites have been consistently reported as having better ecological-character trends than do wetlands generally, between 2011 and 2017, both Ramsar Sites and wetlands generally were reported as having a progressive increasingly widespread deterioration in their eco-logical character. There was a more widespread deterioration -0.2 reported for wetlands generally (ECSI difference -0.244) than for Ramsar Sites (ECSI difference -0.153). 


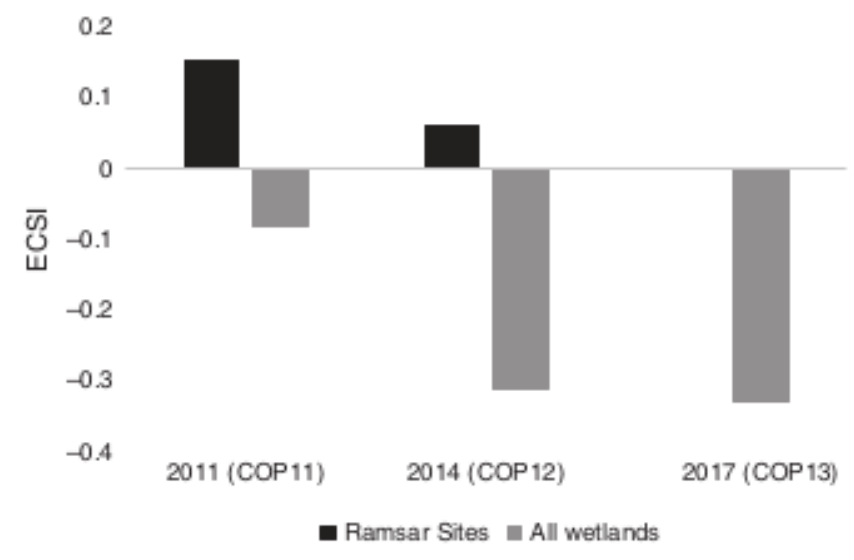

Fig. 5. Comparison of the global-scale Ecological Character-Status Indices (ECSIs) for Ramsar Sites and for wetlands generally reported in 2011 (COP11), 2014 (COP12) and 2017 (COP13). The ECSI for Ramsar Sites in 2017 was 0 (i.e. equal numbers of reports of deterioration and improvement).

\section{Discussion and conclusions}

Although it is encouraging that, in 2011, almost one-quarter (24\%) of governments reported to the Ramsar Convention an improvement in the ecological character of their wetlands generally, this had declined to $13 \%$ in 2014 , and further declined to only $9 \%$ in 2017 . It is of more concern that, in $2011,32 \%$ of governments reported deterioration of their wetlands generally, and that this percentage had risen to over $40 \%$ in 2014 and 2017 . This suggests a rapidly increasing extent of deterioration of the ecological character of the world's wetlands.

Within this global picture, there is some regional variation; however, by 2014, a more widespread deterioration than improvement in the ecological character of wetlands generally was reported from all six Ramsar regions, and from five Ramsar regions in 2017. Deterioration has been most widespread in Africa, Asia and Latin America and the Caribbean, and also, in 2017, in the small number of Oceanian governments that submitted reports.

More encouragingly, the trends in the ecological character for designated Wetlands of International Importance (Ramsar Sites) have been reported by CPs as consistently and significantly better than those for wetlands generally. In 2011, the Ramsar-Site ecological character was improving in 30\% the countries that submitted reports, but this had declined to $25 \%$ in 2014, and further declined to $18 \%$ in 2017; however, it is of concern that almost one-fifth (18\%) of the parties reported deterioration in the ecological character of their Ramsar Site in both 2014 and 2017. As for the status of wetlands generally, in 2017, the worst trends in the ecological character of Ramsar Sites were in Africa, Latin America and the Caribbean and Oceania, and the best were in Asia and Europe.

Deterioration in the ecological character that has been reported at a national scale for Ramsar Sites appears to be related to the average area of Ramsar Sites designated by each $\mathrm{CP}$, with deterioration being reported more often from those countries and regions with the largest average areas of Ramsar Sites. The underlying reasons for this need further investigation. It may be related to the region or to the actual size of the sites, or other reasons such as the length of time since the sites were designated. Because, for Mediterranean wetlands, the ecological character of wetlands with management plans was better than that ofthose without such plans (Treilhes 2012; Korichi and Treilhes 2013), it may be that large Ramsar Sites, most of which are multiple-use systems rather than strict protected areas, are more challenging to manage sustainably, and that many large sites may lack management plans. The ecological-character trends reported here are expert opinions of national government officials in Ramsar Administrative Authorities (AAs). Currently, there is no means of verifying these views; so, we cannot assess the level of accuracy of the trends reported here. However, we consider that the changes in the trends of the ecological character reported between COP national reporting cycles are more analytically robustbecause any biases in report answers are likely to be consistent across time. In the future, if AAs were asked to provide supporting, verifiable, information for their national-report answers on ecologicalcharacter trends, this would enhance confidence in these answers. Nevertheless, these reports do provide the most globally comprehensive coverage currently available on the ecological-character trends of wetlands, and the only such source for wetlands generally (see Davidson et al. 2020). 
It is important to retain this information on the trend in the ecological-character indicator question in future triennial Ramsar national reports, and in a manner consistent with its formulation in previous national reports, so that longer time-series data on change in the ecological-character trends can be assessed. However, some enhancements to the indicator might clarify and enrich the future dataset. First, it is implicit, but not explicit, that answers to the 'wetlands generally' question cover all wetlands in the country, including Ramsar Sites, but it is not clear whether that is how the question has been consistently understood and answered by all CPs. Guidance clarifying this could be included in future national-report cycles. Second, it is not explicit that if a CP did not answer the indicator question, this is because they do not have information on the trends in the ecological character of their wetlands. To clarify this in future, an additional answer option of 'no information' should be added to the indicator questions. Third, asking CPs for information on the ecologicalcharacter trend separately for inland natural wetlands, marine and coastal natural wetlands and human-made wetlands would be informative. Such separate information on inland and marine and coastal wetlands was requested as additional optional information in the COP13 national-report format.

For Ramsar Sites, there are other reporting mechanisms established by the Ramsar Convention, notably concerning the regular updating of information (at not more than 6-year intervals) on the ecological-character change in the Information Sheet on Ramsar Wetlands (RIS) and Article 3.2 reporting on human-induced negative change, or likely change, in the ecological character of Ramsar Sites. However, as Davidson et al. (2020) reported, these reporting requirements are not being adequately complied with, and many RISs are many years (some over 40 years) out of date. Until this requirement to update RISs is fully complied with by Ramsar CPs, the qualitative national-report answers are the most globally comprehensive source of information on the ecological-character change for Ramsar Sites.

The national-report indicator questions on trends in the ecological character do not ask for any reporting on the magnitude of any trends reported, and there is a lack of guidance to those answering these questions as to what might constitute a 'significant' positive or negative trend. So, in our analyses, it is not possible to assess the relative magnitude of the ecologicalcharacter trends reported by different CPs. Although the Ramsar Convention's STRP has been asked by CPs to provide advice on identifying 'limits of acceptable change' (LAC) in the ecological character of wetlands (Ramsar Convention 2008), and a discussion paper on this topic has been issued (Ramsar Convention 2012), preparation of this advice has not been given a priority in the recent work of the STRP.

Despite these issues and limitations in the current quality of reporting, we consider that the Ramsar national-report data are the most consistent that are currently available, and we believe that our analyses from these provide a first global and regional assessment of trends in the state of the world's remaining wetlands. This is important information that is needed to better inform and target national policy-making and on-the-ground management of wetlands, so as to better achieve their wise use and future sustainable development.

The 2030 UN SDG 6 is to 'ensure availability and sustainable management of water and sanitation for all' and includes Target 6.6 to 'protect and restore water-related ecosystems, including mountains, forests, wetlands, rivers, aquifers and lakes'. Indicator 6.6.1 for this target currently tracks changes over time only in the spatial extent of water-related ecosystems and inland open waters, the quantity of water in ecosystems, and the quality of water in ecosystems. However, in addition, it is recommended that countries also incorporate a component to this indicator on change over time of ecosystem health in their ecosystemmonitoring programs (UNEP 2018). Such an indicator is not yet in place. Given that the Ramsar trends in wetland ecological character assessed in the present paper are reported at the national level by governments, they appear to meet the conditions for inclusion as an SDG 6.6.1 indicator on ecosystem health, as an initial expert-opinion measure. We, nevertheless, recommend that the joint custodians of SDG Indicator 6.6.1 (the Ramsar Convention Secretariat and UN Environment Programme) could consider assessing the value of this information as a prelude to potentially incorporating Ramsar wetland ecologicalcharacter trend reporting for wetlands generally and for Ramsar Sites into the SDG indicator process, along with the provision of the supporting information for verification purposes.

Similarly, information on the wetland ecological-character trend we have reported here also has the potential to contribute to assessing achievement of one aspect of Aichi Biodiversity Target 5, namely 'by 2020, the rate of loss of all natural habitats, including forests, is at least halved and where feasible brought close to zero, and degradation and fragmentation is significantly reduced' (available at https://www.cbd.int/sp/targets/, accessed 5 November 2019). Our analyses could help inform the Target 5 indicator on 'proportion of land that is degraded over total land 
area' (see https://www.bipindicators.net, accessed 5 November 2019). Moreover, this information should also be made available to the Intergovernmental Science-Policy Platform on Biodiversity and Ecosystem Services (IPBES) for its assessments on biodiversity and related ecosystem services.

On the basis of these reports from Ramsar CPs, over 45 years after the commitment by the Convention to 'stem the progres-sive encroachment on and loss of wetlands...' was adopted (Ramsar Convention 1971), this is not being achieved, in particular in relation to commitments to ensuring the wise use of all wetlands through the maintenance of their ecological character. Not only is the area of wetlands in a continuing decline through conversion and loss (Davidson 2014; Dixon et al. 2016; Darrah et al. 2019; IPBES 2018), here we have provided evidence that there is also a continuing and increasingly widespread decline in wetland quality in terms of deterioration of the ecological character of the remaining wetlands in all parts of the world.

\section{Conflicts of interest}

Nick Davidson, Robert McInnes, Max Finlayson, Siobhan Fennessy and Patrick Grillas are Editors for Marine and Freshwater Research but did not at any stage have access to this manuscript while in peer review, as is the standard practice when handling manuscripts submitted by an editor to this journal. Marine and Freshwater Research encourages its editors to publish in the journal and they are kept totally separate from the decision-making processes for their manuscripts. Nick David-son was Deputy Secretary General of the Ramsar Convention from 2000 to 2014. Ania Grobicki was Deputy Secretary General from 2015 to 2017 and Acting Secretary General from November 2015 to August 2016. Nick Davidson (2015-2018), Lars Dinesen (2012-2018), Siobhan Fennessy (2015present), C. Max Finlayson (1993-2018), Rob McInnes (2005-2018) and David Stroud (2003-present) have been formally part of the Convention's Scientific and Technical Review Panel (STRP) in line with its appointment procedures. David Stroud, Max Finlayson and Lars Dinesen have also been the respective STRP National Focal Point of the UK, Australian and Danish governments for the periods 1999-2019,1999-2004 and 2012 to the present.

\section{Declaration of funding}

We thank the Institute for Land Water \& Society, Charles Sturt University, Australia, for financial support to the lead author, which facilitated the drafting of this paper.

\section{Acknowledgements}

The development of the ideas presented in this paper were greatly helped by the presentations and discussions in three symposia and workshops organised by the Society of Wetland Scientists' (SWS) Ramsar Section, at SWS annual conferences in 2015 (Providence, Rhode Island, USA) and 2016 (Corpus Christi, Texas, USA) and at the INTECOL 10th International Wetlands Conference (2016: Changshu, China). We thank all participants in these sessions for their most valuable contributions and views on wetlandassessment issues.

\section{References}

- Butchart, S. H. M., Walpole, M., Collen, B., van Strien, A., Scharlemann, J. P. N., Almond, R. E. A., Baillie, J. E. M., Bombard, B., Brown, C., Bruno, J., Carr, G. M., Chenery, A. M., Csirke, J., Davidson, N. C., Detenter, F., Foster, M., Galli, A., Galloway, J. N., Genovesi, P., Gregory, R. D., Hockings, M., Kapos, V., Lamarque, J.-F., Leverington, F., Loh, J., McGeoch, M. A., McRae, L., Minasyan, A., Morcillo, M. H., Oldfield, T. E. E., Pauly, D., Ouader, S., Revenga, C., Skolnik, B., Spear, D., Stanwell-Smith, D., Symes, A., Tierney, M., Tyrell, T. D., Vié, J.C., and Watson, R. (2010). Global biodiversity: indicators of recent declines. Science 328, 1164-1168. doi:10.1126/SCIENCE.1187512

- Carp, E. (Ed.) (1972). 'Proceedings of the International Conference on the Conservation of Wetlands and Waterfowl', 30 January-3 February 1971, Ramsar, Iran. (IWRB: Slimbridge, UK.)

- Darrah, S. E., Shennan-Farpôn, Y., Loh, J., Davidson, N. C., Finlayson, C. M., Gardner, R. C., and Walpole, M. J. (2019). Improvements to the Wetland Extent Trends (WET) index as a tool for monitoring natural and human-made wetlands. EcologicalIndicators 99,294-298. doi:10.1016/ J.ECOLIND.2018.12.032

- Davidson, N. C. (2014). How much wetland has the world lost? Long-term and recent trends in global wetland area. Marine and Freshwater Research 65, 934-941. doi:10.1071/MF14173

- Davidson, N. C., Finlayson, C. M., and Fluet-Chouinard, E. (2018). Global extent and distribution of wetlands: 
trends and issues. Marine and Freshwater Research 69, 620-627. doi:10.1071/MF17019

- Davidson, N. C., van Dam, A. A., Finlayson, C. M., and McInnes, R. J. (2019). The worth ofwetlands: revised global monetary values ofcoastal

- and inland wetland ecosystem services. Marine and Freshwater Research 70(8), 1189-1194. doi:10.1071/MF18391

- Davidson, N. C., Dinesen, L., Fennessy, S., Finlayson, C. M., Grillas, P., Grobicki, A., McInnes, R. J., and Stroud, D. A. (2020). Adequacy of reporting on change in wetland ecological character to the Ramsar Convention on Wetlands by Contracting Parties. Marine and Freshwater Research 71(1), 117-126. doi:10.1071/MF18328

- de Klemm, C. (1995). The Legal Development ofthe Ramsar Convention on Wetlands of International Importance especially as Waterfowl Habitat (2 February 1971). (Ramsar Convention Bureau: Gland, Switzerland) Available at http://www.ramsar.org/cda/en/ramsar-pubs-books-legaldevelopmentof/main/ramsar/1-30-101\%5E23880_4000_0__ [Verified 8 November 2019].

- Dixon, M. J. R., Loh, J., Davidson, N. C., Beltrame, C., Freeman, R., and Walpole, M. (2016). Tracking global change in ecosystem area: the Wetland Extent Trends Index. Biological Conservation 193, 27-35. doi:10.1016/J.BIOCON.2015.10.023

- Finlayson, C. M., Davidson, N. C., Spiers, A. G., and Stevenson, N. J. (1999). Global wetland inventory: current status and future priorities. Marine and Freshwater Research 50, 717-727. doi:10.1071/MF99098

- Finlayson, C. M., D'Cruz, R., and Davidson, N. (2005). Ecosystems and human well-being: Wetlands and Water. Synthesis. Millennium Ecosystem Assessment. World Resources Institute, Washington, DC, USA.

- IPBES (2018). 'Summary for Policymakers of the Thematic Assessment Report on Land Degradation and Restoration of the Intergovernmental Science-Policy Platform on Biodiversity and Ecosystem Services.' (IPBES Secretariat: Bonn, Germany.)

- IPCC (2019). Global warming of $1.5^{\circ} \mathrm{C}$. An IPCC special report on the impacts of global warming of $1.5^{\circ} \mathrm{C}$ above pre-industrial levels and related global greenhouse gas emission pathways, in the context of strengthening the global response to the threat of climate change, sustainable development, and efforts to eradicate poverty. Intergovernmental Panel on Climate Change, Geneva, Switzerland.

- Korichi, N., and Treilhes, C. (2013). Les sites Ramsar assurent leur rôle de protection quand ils sont gérés. Espaces Naturels 43, 14-15.

- Matthews, G. V. T. (1993). 'The Ramsar Convention on Wetlands: its History and Development.' (Ramsar Convention Bureau: Gland, Switzerland.)

- Moomaw, W. R., Chmura, G. L., Davies, G. T., Finlayson, C. M., Middleton, B. A., Perry, J. E., Roulet, N., and Sutton-Grier, A. E. (2018). The relationship between wetlands and a changing climate: science, policy and management. Wetlands38, 183-205. doi:10.1007/S13157-018-1023-8

- Ramsar Convention (1971). Convention on Wetlands of International Importance Especially as Waterfowl Habitat. Final text adopted by the International Conference on the Wetlands and Waterfowl at Ramsar, Iran, 2 February 1971. Available at http://ramsar.rgis.ch/cda/en/ramsar-documents-texts-convention-on20708/main/ramsar/1-31-38\%5E20708_4000_0__ [Verified 8 November 2019].

- Ramsar Convention (2005). A conceptual framework for the wise use of wetlands and the maintenance of their ecological character. Resolution IX.1 Annex A. Available at http://www.ramsar.org/sites/default/files/ documents/pdf/res/key_res_ix_01_annexa_e.pdf [Verified 8 November 2019].

- Ramsar Convention (2008). Resolution X.10. Future implementation of scientific and technical aspects of the Convention. Available at https:// www.ramsar.org/sites/default/files/documents/pdf/res/key_res_x_10_e. pdf [Verified 8 November 2019].

- Ramsar Convention (2012). Ramsar COP11 DOC. 24. Limits of acceptable change. Available at https://www.ramsar.org/sites/default/files/docu-ments/pdf/cop11/doc/cop11-doc24-e-limits.pdf [Verified 8 November 2019].

- Ramsar Convention on Wetlands (2018). 'Global Wetland Outlook: State of the World's Wetlands and their Services to People.' (Ramsar Convention Secretariat: Gland, Switzerland.)

- Ramsar Convention Secretariat (2011). Ramsar's liquid assets. 40 years of the Convention on Wetlands. Available at http://www.ramsar.org/pdf/ Ramsar40_booklet/Ramsar_LiquidAssets_E.pdf [Verified 8 November 2019].

- Ripple, W. J., Wolf, C., Newsome, T. M., Barnard, P., and Moomaw, W. R. (2019). World scientists' warning of a climate emergency. Bioscience, biz088. doi:10.1093/BIOSCI/BIZ088

- Treilhes, C. (2012). Les caractéristiques écologiques d'une zone humide influencent-elles sa conservation? 
M.Sc. Thesis, Master II Ecologie, Biodiversitéet Evolution (MNHN), UniversitéPierre-et-Marie-Curie, Paris, France.

- United Nations Environment Programme (2018). Indicator 6.6.1: waterrelated ecosystems. Available at http://www.sdg6monitoring.org/indicators/target-66/indicators661/ [Verified 8 November 2019].

- Wetlands International (2010). 'State of the World's Waterbirds 2010.' (Wetlands International: Ede, Netherlands.) 